\title{
Social media and the workplace: "could loose lips cost you a pink slip?"
}

\author{
Peter Kalina \\ Department of Radiology, Mayo Clinic, Rochester, MN, USA \\ Correspondence to: Peter Kalina, MD, MBA, FACR. Professor of Radiology, Mayo Clinic, Rochester, MN, USA. Email: kalina.peter@mayo.edu.
}

Received: 19 March 2020. Accepted: 30 March 2020; Published: 25 June 2020.

doi: 10.21037/jhmhp.2020.03.05

View this article at: http://dx.doi.org/10.21037/jhmhp.2020.03.05

Two recent articles in The Economist $(1,2)$ ask some intriguing questions, and provide for interesting debate. Should we have free speech at work? What about outside of work? Do organizations have a right to silence their employees? Can you be fired for posting an opinion on Twitter? How about just clicking "like" on somebody else's controversial Facebook post? Surprisingly, and unfortunately, the answer is often; "yes." Employees have been fired based on their social media content.

Understandably, companies worry about what their employees say and write-at work and outside the office - even when their posts are unrelated to work. With a quick click, social media broadcasts our thoughts and controversial opinions far beyond their origins at the neighborhood pub. Some colleagues and companies may not approve of the content. Anyone who's offended can easily retaliate. Some companies spell out expectations in codes of conduct and social medial policies. General Motors' 12-page policy (3) polices workers' speech-even when they're not at work; "your online communications will not be excused merely because they occurred outside of work hours or off GM premises." [Mayo Clinic has a social media policy (4). Please note that this letter does not refer to those guidelines, which can be found at https:// socialmedia.mayoclinic.org/mayo-clinic-employee-socialmedia-guidelines].

The Economist articles' author's concede that organizations can't be blamed for looking out for their selfinterest. They need to promote and protect their brand and their reputation. Sometimes this may require punishing workers who "speak out." We know all too well that "the ship must continue moving forward," and that for some organizations, "the ship is more important than the people moving it." Though it's not necessarily in an institution's best interest to allow free expression of opinion, it is in society's best interest. While free speech is a cornerstone of our democracy, too often workers are made to tone down their rhetoric and keep their thoughts to themselves.

Most employees probably have very little protection against punitive employers. Laws that exist to protect our religious freedoms do not extend to other views. In fact, employees and employers are often unsure which views are acceptable; and which are not. While most would argue that it's not fair to fire someone for speaking their mind, we can all agree that there are major differences between offending and harassing. One must be careful not to cross that line.

There also needs to be a distinction between what we do at work and outside of work. The articles suggest that speech is like a dress code. Companies can demand their employees look the part while at work. Perhaps it's ok that they restrict what employees say there, provided they do so clearly, transparently, and consistently. After people go home, though, they should be able to express their opinions freely; just as they are free to change into their ripped jeans and favorite old T-shirt.

Ideally, in the absence of subjectivity and bias, nobody should be treated differently at work or passed up for positions or promotions for (legal and non-harassing) activities outside of work. Employers will argue they need to restrict the expression of certain views to create inclusive workplaces, protect employees from hostility, and protect themselves from litigation (and bad press!). Is firing or reprimanding someone with views different from "the norm" the opposite of inclusivity?

Social media is a huge part of our culture. Culture is a huge part of our workplaces. To enhance employee wellness, 
our work and non-work spaces should be segregated. We should be able to "bring our whole selves to work" and embrace our different viewpoints at work. If we can't express ourselves freely outside of work, where can we do so?

\section{Acknowledgments}

Funding: None.

\section{Footnote}

Provenance and Peer Review: This article was a standard submission to the journal. The article was sent for external peer review.

Conflicts of Interest: The author has completed the ICMJE uniform disclosure form (available at http://dx.doi. org/10.21037/jhmhp.2020.03.05). The author has no conflicts of interest to declare.

Ethical Statement: The author is accountable for all aspects of the work in ensuring that questions related to the accuracy or integrity of any part of the work are appropriately investigated and resolved.

Open Access Statement: This is an Open Access article distributed in accordance with the Creative Commons Attribution-NonCommercial-NoDerivs 4.0 International License (CC BY-NC-ND 4.0), which permits the noncommercial replication and distribution of the article with the strict proviso that no changes or edits are made and the original work is properly cited (including links to both the formal publication through the relevant DOI and the license). See: https://creativecommons.org/licenses/by-nc-nd/4.0/.

\section{References}

1. Working nine to five. The Economist (February 27, 2020). P10.

2. None of your business. The Economist (February 27, 2020). P47.

3. Social Media Policy. General Motors. Available online: https://www.gm.com/full-social-media-policy.html

4. Mayo Clinic Social Media Guidelines. Available online: https://socialmedia.mayoclinic.org/mayo-clinic-employeesocial-media-guidelines/ doi: 10.21037/jhmhp.2020.03.05

Cite this article as: Kalina P. Social media and the workplace: "could loose lips cost you a pink slip?" J Hosp Manag Health Policy 2020;4:18. 